Aim of the study: The aim of our studies was to assess the influence of paclitaxel on the expression of selected activating transcriptional factors in ductal breast cancer primary cells using the microarray technique.

Material and methods: The cells were treated with $60 \mathrm{ng} / \mathrm{ml}$ and $300 \mathrm{ng} / \mathrm{ml}$ doses of paclitaxel. Administered dose concentrations corresponded to those applied in breast cancer mono- and polytherapy and also covered the number of chemotherapy cycles. The control breast cancer cells in vitro were not treated with a cytostatic drug.

Results: Sixteen among 21 analysed genes indicated statistically significant increased expression in the cells incubated with $60 \mathrm{ng} / \mathrm{ml}$ of paclitaxel: 15 genes in the 1.8-3.3 fold range $(p<0.05)$, but ETS1 gene expression level increased 4.7-fold in comparison to the control cells. The higher dose of $300 \mathrm{ng} / \mathrm{ml}$ of paclitaxel caused a cytotoxic effect in the cells and a statistically non-significant decrease in expression of all studied genes.

Conclusions: In summary it may be stated that a $60 \mathrm{ng} / \mathrm{ml}$ dose of paclitaxel caused increased expression of analysed genes coding transcriptional activating factors that enhance the studied taxane's mechanism of action. Thus we can suppose that these changes in gene expression values may constitute prognostic and predictive factors in ductal breast cancer therapy. The obtained results encourage us to carry out further studies on the functions and relations between genes and their products.

Key words: breast cancer, transcriptional activators, paclitaxel, microarrays.

\section{Analysis of expression of selected genes coding transcriptional activators in ductal breast cancer cells in vitro treated with paclitaxel}

\author{
Analiza ekspresji wybranych genów kodujących aktywatorowe \\ czynniki transkrypcyjne w komórkach przewodowego raka piersi \\ in vitro poddanych dziataniu paklitakselu
}

\section{Marta Ziaja-Sołtys, Jolanta Rzymowska}

Katedra i Zakład Biologii z Genetyką, Uniwersytet Medyczny w Lublinie

\section{Wstęp}

Nowotwór piersi jest chorobą, która wykazuje szeroki zakres cech histologicznych, klinicznych i genetycznych [1]. Rak przewodowy in situ (łac. carcinoma intraductale - DCIS), heterogenny, nieinwazyjny stanowi obecnie 25-30\% nowo diagnozowanych nowotworów piersi. Charakteryzują go nowotworowe komórki nabłonkowe gromadzące się w przewodach gruczołu piersiowego, bez naciekania przez błonę podstawną do otaczającej tkanki [2]. Polska jest krajem o średniej zachorowalności na raka piersi, a najbardziej dynamiczny wzrost zapadalności na tę chorobę obserwuje się u kobiet w wieku 35-39 lat [3]. Zgodnie z danymi Polskiego Krajowego Rejestru Nowotworów Złośliwych w 2006 r. zarejestrowano ponad 13000 nowych zachorowań wśród kobiet oraz ponad 5000 zgonów spowodowanych przez ten nowotwór [4].

Aktywacja genów jest złożonym, wieloetapowym procesem, przygotowującym maszynerię transkrypcyjną. Aktywatory to czynniki transkrypcyjne oddziałujące bezpośrednio z DNA i przyłączające się do sekwencji dalszego promotora i sekwencji enhancerów. Grupa aktywatorów i koaktywatorów obejmuje zarówno czynniki ogólnego działania aktywne w transkrypcji wielu genów, jak i czynniki specyficzne uczestniczące w wybiórczej aktywacji genów zależnej od rodzaju tkanki czy etapu rozwoju organizmu [5].

Jednym z powszechnie stosowanych leków w terapii wielu nowotworów, w tym raka piersi, jest antymitotyczny paklitaksel [6]. Mechanizm działania taksolu polega na łączeniu się z podjednostką $\beta$-tubuliny, głównego białka wrzeciona mitotycznego, i tworzeniu stabilnych i niefunkcjonalnych pęczków mikrotubul, co powoduje zablokowanie cyklu komórkowego na granicy faz G2/M i uniemożliwia dalszą proliferację [7]. Stwierdzono, że w odróżnieniu od innych leków przeciwnowotworowych wykazujących działanie genotoksyczne na DNA komórek neoplastycznych taksol nie wywołuje uszkodzenia materiału genetycznego [8]. Wykazano, że chemioterapia z udziałem taksanów pozytywnie wpływa na wyniki leczenia wczesnego raka piersi [9]. Obecnie coraz powszechniej stosowana technika mikromacierzy otwiera nowe perspektywy w medycynie oraz farmacji. Charakterystyka profilu ekspresji genów w stanach patologicznych umożliwia szybsze i skuteczniejsze diagnozowanie chorób, prognozowanie ich przebiegu oraz odpowiedni wybór leków w zależności od indywidualnych potrzeb pacjenta [10].

Celem badań była ocena wpływu paklitakselu na ekspresję genów kodujących wybrane aktywatorowe czynniki transkrypcyjne w komórkach przewodowego raka piersi in vitro. 
Cel pracy: Celem badań była ocena wpływu paklitakselu na ekspresję genów kodujących wybrane aktywatorowe czynniki transkrypcyjne w komórkach in vitro przewodowego raka piersi za pomocą techniki mikromacierzy. Materiał i metody: Do pierwotnych hodowli komórek przewodowego raka piersi podawano paklitaksel w stężeniach $60 \mathrm{ng} / \mathrm{ml}$ i $300 \mathrm{ng} / \mathrm{ml}$. Obliczone stężenia odpowiadały dawkom stosowanym w mono- i politerapii raka piersi, a także uwzględniały liczbę przeprowadzanych cykli chemioterapii paklitakselem. Równocześnie prowadzono hodowle kontrolne komórek nabłonkowych przewodowego raka piersi, które inkubowano bez cytostatyku.

Wyniki: Szesnaście z 21 badanych genów wykazało istotny statystycznie wzrost ekspresji w hodowlach komórek przewodowego raka piersi poddanych dziataniu dawki $60 \mathrm{ng} / \mathrm{ml}$ paklitakselu: 15 genów w zakresie 1,8-3,3 ( $p<0,05)$, natomiast poziom ekspresji genu ETS1 wzrósł 4,7-krotnie $(p=0,0227)$ w porównaniu z komórkami kontrolnymi. Druga stosowana dawka paklitakselu $300 \mathrm{ng} / \mathrm{ml}$ spowodowała w hodowlach efekt cytotoksyczny oraz nieistotny statystycznie spadek ekspresji wszystkich analizowanych genów w odniesieniu do komórek kontrolnych.

Wnioski: Podsumowując, można stwierdzić, że wprowadzenie dawki $60 \mathrm{ng} / \mathrm{ml}$ cytostatyku do hodowli komórek przewodowego raka piersi spowodowało wzrost ekspresji genów dla czynników transkrypcyjnych, wzmacniających mechanizm działania badanego taksanu. Dlatego też można przypuszczać, że wartość ekspresji badanych genów dla aktywatorów transkrypcji w komórkach przewodowego raka piersi może stanowić czynnik prognostyczny i predykcyjny. Uzyskane wyniki skłaniają do dalszego badania funkcji analizowanych genów i ich produktów oraz istniejących między nimi zależności.

Stowa kluczowe: rak piersi, aktywatory transkrypcji, paklitaksel, mikromacierze.

\section{Materiat i metody}

Badane komórki otrzymano z tkanek gruczołów piersiowych pobranych od 36 pacjentek, hospitalizowanych w Centrum Onkologii Ziemi Lubelskiej, z wykrytym przewodowym rakiem piersi podczas zabiegu mastektomii. Pacjentki nie były poddane żadnej chemioterapii. Materiał weryfikowano histopatologicznie: obejmował on przypadki raka piersi w I i II stadium rozwoju wg klasyfikacji Blooma (rak przedinwazyjny i zmiany do wielkości ok. $2 \mathrm{~cm}$, bez przerzutów do węzłów chłonnych).

Pobrany materiał poddawano homogenizacji mechanicznej (homogenizator kulkowy), a następnie enzymatycznej (0,01-procentowa trypsyna; WSiSz Lublin) i zakładano pierwotne hodowle komórek przewodowego raka piersi w jednorazowych naczyniach plastikowych o powierzchni $25 \mathrm{~cm}^{2}$ w podłożu RPMI (SIGMA) z dodatkiem płodowej surowicy bydlęcej (FBS, SIGMA) oraz penicyliny i streptomycyny (370C, w atmosferze zawierającej 5\% dwutlenku węgla, przy 90-procentowej wilgotności powietrza). Do hodowli, które osiągnęły gęstość 10000 komórek/ml, dodawano paklitaksel (Bristol - Myers Squibb; Anglia) w stężeniach 60 ng/ml i 300 ng/ml, a następnie inkubowano je przez 72 godz. Dozowane stężenia cytostatyku przeliczano na podstawie dawki terapeutycznej, która wynosi $175 \mathrm{mg} / \mathrm{m}^{2}$ powierzchni ciała. Hodowle prowadzono w naczyniach Falcona o powierzchni $25 \mathrm{~cm}^{2}$, stąd przelicznik dawki terapeutycznej stosowanej w badaniach autorek niniejszej pracy wynosił $60 \mathrm{ng}$. Wartość pięciokrotnie wyższej, zastosowanej w badaniach dawki wynika z przeliczenia na 6 cykli chemioterapii. Zakładane hodowle po 72 godz. tworzyły monolayer, dlatego też stężenie cytostatyku podano w jednostkach wagowo-objętościowych, tj. 60 ng i 300 ng na mililitr podłoża hodowlanego. Równocześnie prowadzono hodowle kontrolne komórek nabłonkowych przewodowego raka piersi, które inkubowano bez cytostatyku, ale z dodatkiem 5-procentowego dimetylosulfotlenku (DMSO).

Z komórek przewodowego raka piersi kontrolnych i z dodatkiem paklitakselu wyizolowano całkowite RNA (T RNA) przy użyciu zestawu TRI (SIGMA) zgodnie z procedurą producenta. Do czasu wykonania kolejnych etapów analizy T RNA przechowywano w temperaturze $-70^{\circ} \mathrm{C}$.

Komplementarny DNA (cDNA) otrzymano w reakcji odwrotnej transkrypcji przy użyciu standardowego zestawu (SIGMA), a następnie poddano procesowi hybrydyzacji (zestaw Panorama Human Cancer cDNA Labeling and Hybrydization Kit; CDLBL-HCN, SIGMA-GENOSIS). Do próbek zawierających mieszaninę reakcyjną do odwrotnej transkrypcji dodano RNA pochodzący z genu wzorcowego Escherichia coli (z zestawu hybrydyzacyjnego Panorama Armored RNA E. coli-B 1444 RNA), dzięki czemu możliwe było późniejsze skalibrowanie aktywności innych genów zawartych na podłożu macierzy w odniesieniu do ekspresji tego genu. Otrzymano cDNA z wyznakowanymi radioaktywnym ${ }^{32}$ P resztami trójfosforanu dezoksyrybocytozyny. Proces oczyszczania przeprowadzono w kolumnie Sephadex G-25. Oczyszczony cDNA poddano procesowi hybrydyzacji na macierzy firmy (SIGMA-GENOSIS), zawierającej sekwencje genów kodujących różne grupy białek związanych z regulacją procesów nowotworowych oraz sekwencje genu wzorcowego. Wstępna faza obejmowała przygotowanie nylonowego podłoża matrycy. W tym celu do pojemnika z matrycą dodano roztwór hybrydyzacyjny, w skład którego wchodził testowy DNA tososia (SIGMA-GENOSIS kit CDBL-HCN). Hybrydyzację prowadzono w piecu hybrydyzacyjnym Bachover GmbH-D7410. Następnie matrycę umieszczono w kasecie wychwytującej promieniowanie $\gamma$ (detektor promieniowania Screen Imaging K, Bio-Rad). Czas pomiaru aktywności wynosit ok. 24 godziny. Promieniowanie $\gamma$ pochodzące z punktów odpowiadających genom na matrycy powodowało przemiany chemiczne promienioczułego nośnika zawartego w kasecie (podłoże z soli fluorobromowej z naniesionym na nie Europem). Nośnik ten po napromienieniu skanowano na skanerze Molecular Image FX (Bio-Rad) o rozdzielczości 50 mikronów, otrzymując w ten sposób obraz ekspresji genów na matrycy. Otrzymane zdjęcie przenoszono w postaci pliku na dysk komputera. Ekspresję z poszczegól- 


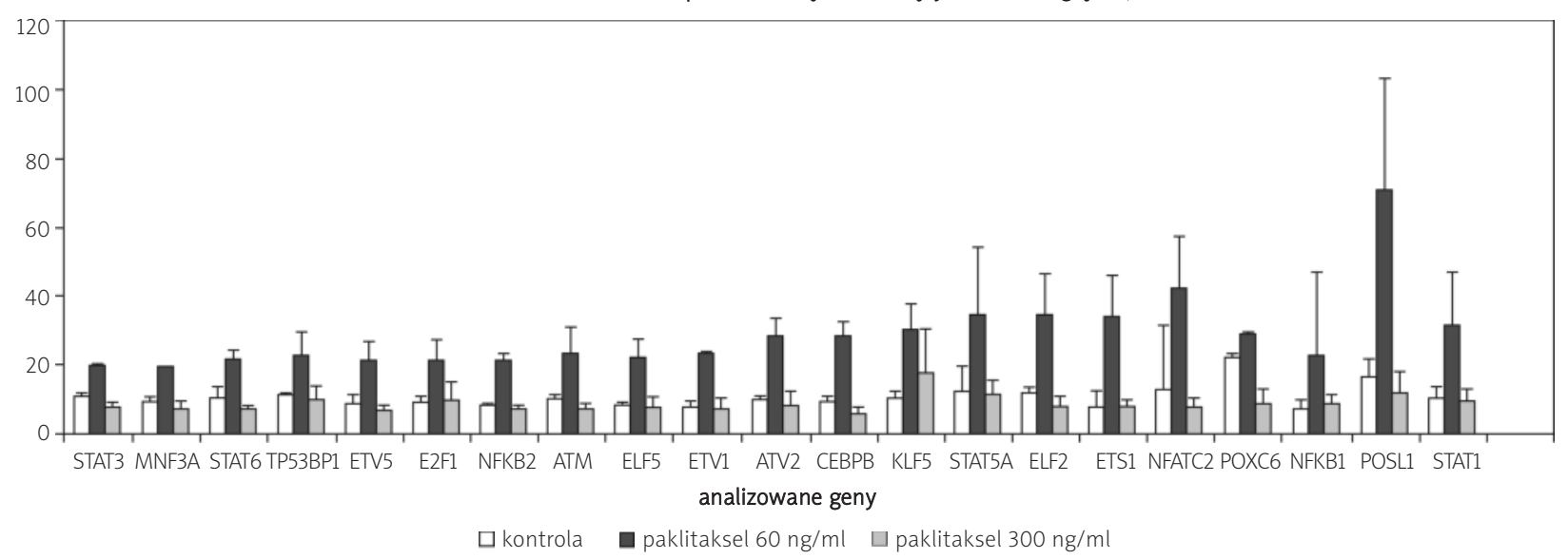

Fig. 1. Arithmetical means and standard deviations of expression values for all (21) studied genes coding activating transcriptional factors in ductal breast cancer control cells in vitro and treated with $60 \mathrm{ng} / \mathrm{ml}$ and $300 \mathrm{ng} / \mathrm{ml}$ doses of paclitaxel

Ryc. 1. Średnie arytmetyczne i odchylenia standardowe wartości ekspresji wszystkich (21) badanych genów kodujących czynniki transkrypcyjne pełniące funkcję aktywatorów w komórkach kontrolnych in vitro przewodowego raka piersi oraz poddanych działaniu dawek $60 \mathrm{ng} / \mathrm{ml}$ i $300 \mathrm{ng} / \mathrm{ml}$ paklitakselu

nych punktów matrycy normalizowano z poziomem ekspresji genu wzorcowego E. coli, zlokalizowanego w punktach kontrolnych. Do analizy ekspresji genów matrycy wykorzystano program komputerowy Quantity One - wersja 4.2.1. Za miarę poziomu ekspresji w poszczególnych polach przyjęto średnią liczbę zliczeń na piksel przypadającą na określoną jednostkę powierzchni (tzw. powierzchnię wzorcową odpowiadającą położeniu pojedynczego genu na matrycy). Analiza wyników polegała na porównaniu ekspresji badanych genów w hodowlach komórek raka piersi poddanych działaniu paklitakselu z ekspresją tych genów $w$ hodowlach kontrolnych. Badania przeprowadzono w trzech niezależnych powtórzeniach z użyciem jednego zestawu odczynników. Przeanalizowano ekspresję 21 genów, kodujących aktywatory procesu transkrypcji. Analizę statystyczną otrzymanych wyników przeprowadzono za pomocą programu Microsoft Office Excel 2003.

1. Policzono wartości średnich arytmetycznych i odchyleń standardowych dla ekspresji poszczególnych genów.

2. W celu oceny istotności różnic pomiędzy ekspresją badanych genów posłużono się testem t-Studenta. Za istotne statystycznie były przyjmowane wartości dla istotności $p<0,05$.

\section{Wyniki}

W pracy analizowano ekspresję 21 genów dla aktywatorowych czynników transkrypcyjnych, z których 16 wykazato istotny statystycznie wzrost ekspresji w hodowlach komórek przewodowego raka piersi poddanych działaniu dawki 60 ng/ml paklitakselu. Druga stosowana dawka paklitakselu 300 ng/ml spowodowała efekt cytotoksyczny w hodowlach in vitro komórek przewodowego raka piersi oraz nieistotny statystycznie spadek ekspresji wszystkich analizowanych genów w odniesieniu do komórek kontrolnych nieinkubowanych z lekiem (ryc. 1).

Piętnaście genów wykazało 1,8-3,3-krotny wzrost wartości ekspresji w hodowlach komórek z dawką 60 ng/ml leku w porównaniu z ich ekspresją w komórkach kontrolnych.
Najwyższy wzrost poziomu ekspresji - 4,7-krotny - zanotowano natomiast dla genu ETS1 (ryc. 2).

\section{Dyskusja}

Regulacja ekspresji genów jest najbardziej fundamentalnym procesem w biologii i wywiera ogromny wpływ na komórki całego organizmu. Błędy pojawiające się w aktywacji genowej przez zbyt wysoką albo niską ekspresję określonego genu mogą często prowadzić do wystąpienia choroby. Najlepiej znanym przykładem jest ekspresja onkogenów, gdzie skutkiem transkrypcji pojedynczego genu może być transformacja nowotworowa [11].

W przeprowadzonych badaniach najwyższy wzrost ekspresji stwierdzono dla genu kodującego czynnik ETS1 należący do grupy czynników powszechnie aktywnych i funkcjonujących jako aktywatory promotorów w ludzkich komórkach raka piersi [12]. ETS1 i ETV5 ulegają ekspresji w większości zaawansowanych guzów pochodzenia nabłonkowego i uważa się, że odgrywają ważną rolę w rozwoju i progresji nowotworu, a ponadto są niezależnymi czynnikami prognostycznymi w raku piersi [13]. W nowotworach piersi czynnik ETS1 pozytywnie reguluje indukowaną metaloproteinazą macierzy 1 (MMP-1) ekspresję genu HER2 [14]. Innym czynnikiem grupy ETS jest białko kodowane przez badany gen ETV1, odgrywające znaczącą rolę w nowotworzeniu, w którym pośredniczy gen HER-2/Neu [15]. Podobnie, gen ATF2 koduje potencjalny czynnik transkrypcyjny odpowiedzialny za indukowaną TGF- $\beta$ pozytywną regulację metaloproteinazy macierzy 2 (MMP-2), prowadzącą do progresji nowotworowej ludzkich komórek nabłonkowych gruczołu piersiowego [16]. Liczne badania wykazały, że ekspresja FOXA1 (HNF-3 $\alpha$ ) jest silnie skorelowana z genem ESR1 dla estrogenu w komórkach raka piersi z podtypem luminalnym A, a także znaczącym czynnikiem rokowniczym dla pacjentek z nowotworami estrogenopozytywnymi [17, 18].

Czynniki transkrypcyjne rodziny STAT stają się aktywne w odpowiedzi na cytokiny i czynniki wzrostu [19]. Ekspresja genu STAT5 w nowotworach piersi, szczególnie we wczes- 
Table 1. Analyzed genes of activatory transcription factors

Tabela 1. Analizowane geny, kodujące aktywatorowe czynniki transkrypcyjne

\begin{tabular}{|c|c|}
\hline \multicolumn{2}{|l|}{ Gen } \\
\hline ELF5 & gen kodujący czynnik transkrypcyjny ELF5 (czynnik transkrypcyjny mający domenę ETS) \\
\hline ATF2 & gen kodujący aktywator transkrypcyjny 2 \\
\hline ETV1 & gen kodujący czynnik transkrypcyjny ETV1 formę genu 1 \\
\hline STAT5A & gen kodujący przekaźnik sygnalizacyjny i aktywator transkrypcyjny 5A \\
\hline ETS1 & onkogen v-ets erytroblastozy, homolog 1 wiusa E26 u ptaków \\
\hline FOXO3 & gen kodujący czynnik transkrypcyjny mający domenę \\
\hline$K L F 5$ & gen kodujący czynnik transkrypcyjny podobny do czynnika 5 Kruppel (jelito cienkie) \\
\hline NFKB1 & gen kodujący jądrowy czynnik transkrypcyjny $1 \kappa$ dla wzmacniacza lekkiego łańcucha polipeptydowego w leukocytach B \\
\hline ETV5 & gen kodujący czynnik transkrypcyjny ETV5 homologiczny do genu 5 \\
\hline NFATC2 & gen kodujący jądrowy czynnik aktywujący limfocyty T oraz cytoplazmatyczny, zależny od kalcineuryny 2 \\
\hline NFKB2 & gen kodujący jądrowy czynnik transkrypcyjny $2 \kappa$ dla wzmacniacza lekkiego łańcucha polipeptydowego w leukocytach B \\
\hline ATM & gen kodujący czynnik transkrypcyjny ATM dla zmutowanego genu ataxia telangiectasia (zawierający komplementarne grupy A, C, D) \\
\hline HNF3A & gen kodujący czynnik transkrypcyjny mający domenę forkhead box A1 \\
\hline TP53BP1 & gen kodujący białko wiążące białko P53 \\
\hline E2F1 & gen kodujący czynnik transkrypcyjny1 rodziny E2F \\
\hline FOSL1 & gen kodujący czynnik transkrypcyjny podobny do antygenu 1 należącego do grupy białek FOS1 \\
\hline$C E B P B$ & gen kodujący białko wiążące wzmacniacz dla sekwencji CCAAT \\
\hline STAT1 & gen kodujący przekaźnik sygnalizacyjny i aktywator transkrypcyjny 1, 91 kDa \\
\hline STAT6 & gen kodujący przekaźnik sygnalizacyjny i aktywator transkrypcyjny 6, indukowany interleukiną 4 \\
\hline ELF2 & gen kodujący czynnik transkrypcyjny ELF2 podobny do E74 (czynnik transkrypcyjny rodziny ETS) \\
\hline STAT3 & gen kodujący przekaźnik sygnalizacyjny i aktywator transkrypcyjny 3 \\
\hline
\end{tabular}

Wzrost poziomu ekspresji badanych genów w komórkach inkubowanych z $60 \mathrm{ng} / \mathrm{ml}$ PTX w odniesieniu do kontroli

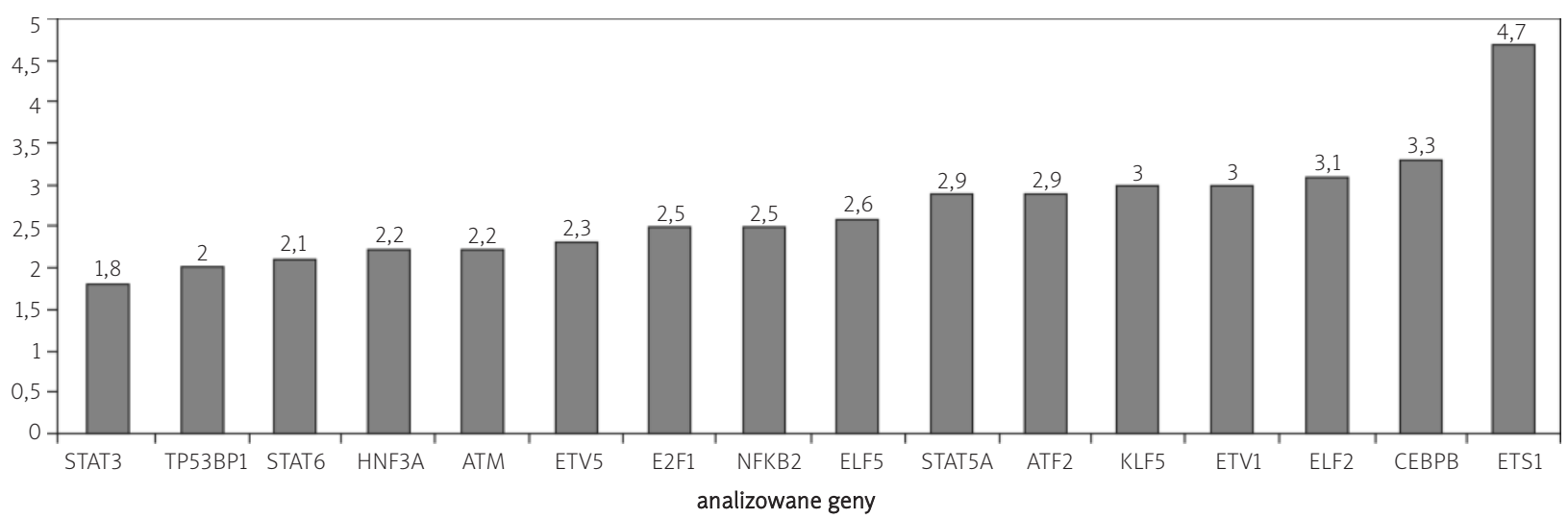

Fig. 2. Statistically significant values of 16 genes expression increment level in ductal breast cancer cells in vitro treated with 60 ng/ml dose of paclitaxel in comparison to control cells

Ryc. 2. Istotne statystycznie wartości wzrostu poziomu ekspresji 16 genów w komórkach przewodowego raka piersi in vitro poddanych działaniu dawki $60 \mathrm{ng} / \mathrm{ml}$ paklitakselu w odniesieniu do komórek kontrolnych

nych etapach raka, zanim powstana przerzuty do węłów chłonnych, pozwala na przewidywanie zmniejszonego ryzyka nawrotu choroby i śmierci [20]. Gen STAT3 koduje onkogenną proteinę stale aktywną w 30-60\% pierwotnych raków piersi. Zidentyfikowano geny negatywnie regulowane przez STAT3, np. c-Myc, oraz geny dla cykliny-D1, Bcl-xL,
Mcl-1 i Bcl-2. Wiadomo również, że białko STAT6 uczestniczy w zahamowaniu wzrostu i indukcji apoptozy przez interleukinę 4 w komórkach raka piersi [21].

Aktywatorowe czynniki transkrypcyjne kodowane przez geny E2F1, ATM i TP53BP1 odgrywają ważną rolę w zachowaniu stabilności genomu, a także ochronie komórki przed 
transformacją nowotworową poprzez regulację ekspresji genu P53. Wiadomo także, że zwiększenie progu regulacji P53 i P21 jest głównym sugerowanym mechanizmem indukowania apoptozy przez taksany.

Wzrost ekspresji genu E2F1 indukuje komórki wyciszone do wejścia w fazę S, co koreluje z aktywacją transkrypcji np. genów dla cykliny E i D1 [22], a białko E2F1 w nadekspresji indukuje zarówno zależną od P53, jak i niezależną apoptozę i reguluje promotor BRCA1 i RB u ludzi [23]. Wyniki wielu badań in vivo i in vitro sugerują, że niska ekspresja ATM w komórkach raka piersi koreluje z występowaniem mutacji DNA, ze zwiększoną angiogenezą, a zatem progresywnym fenotypem nowotworu [24]. Konserwatywne białko jądrowe wiążące P53 - TP53BP1 - jest głównym przekaźnikiem sygnałów o uszkodzeniu DNA do P53 i innych białek supresorowych nowotworów [25].

Nabłonkowo specyficzne czynniki ELF-3 i ELF-5 funkcjonują w komórkach zróżnicowanych. Wykazano, że białko ELF-3 zlokalizowane w cytoplazmie pośredniczy w onkogenezie komórek gruczołu piersiowego [26].

Komórki nowotworowe piersi są zwykle otoczone przez desmoplazję, która jest nagromadzeniem fibroblastów, stanowiącym strukturalne i biochemiczne wsparcie dla guza. Cytokiny wydzielane przez komórki nabłonkowe raka piersi działają na stromę fibroblastów i powodują obniżenie aktywności C/EBP $\alpha$ [27].

Gen KLF5 o podwyższonej ekspresji w obecności niższej badanej dawki paklitakselu koduje białko należące do czynników transkrypcyjnych rodziny Krüppel-like, zaangażowanych w wielu etapach nowotworzenia, włączając kontrolę wzrostu komórek, apoptozę i angiogenezę [28]. Wiadomo, że geny indukowane przez czynnik NF-кB, stale aktywny w nowotworach piersi, chronią komórki rakowe przed działaniem paklitakselu [29].

Podsumowując, można stwierdzić, że wprowadzenie dawki 60 ng/ml cytostatyku do hodowli komórek przewodowego raka piersi spowodowało wzrost ekspresji genów dla czynników transkrypcyjnych wzmacniających mechanizm działania badanego taksanu. Dlatego też można przypuszczać, że wartość ekspresji badanych genów dla aktywatorów transkrypcji w komórkach przewodowego raka piersi może stanowić czynnik prognostyczny i predykcyjny.

\section{Piśmiennictwo}

1. Korkola JE, Blaveri E, DeVries S, et al. Identification of a robust gene signature that predicts breast cancer outcome in independent data sets. BMC Cancer 2007; 7: 61 (doi: 10.1186/1471-2407-7-61).

2. Hannemann J, Velds A, Halfwerk JBG, et al. Classification of ductal carcinoma in situ by gene expression profiling. Breast Cancer Res 2006; 8: R61 (doi:10.1186/bcr1613).

3. Humańska M, Nowicki A. Postępowanie dodatkowe i alternatywne u kobiet chorych na raka piersi. Współcz Onkol 2005; 9: 263-8.

4. http://85.128.14.124/krn/, dostęp z listopada 2008 r.

5. Genetyka molekularna. Węgleński P (ed.). Wydawnictwo Naukowe PWN, Warszawa 2006.

6. Bodnar L, Wcisło G, Miedzińska-Maciejewska M, Szczylik C. Docetaksel i paklitaksel: porównane ich budowy, farmakologii oraz mechanizmów oporności. Współcz Onkol 2004; 8: 435-46.

7. Dozier JH, Hiser, Davis JA, et al. Beta class II tubulin predominates in normal and tumor breast tissues. Breast Cancer Res 2003; 5 : R157-R169.
8. Górecka KM, Gawęcki W, Szyfter K. Brak aktywności genotoksycznej preparatu paklitaksel w limfocytach eksponowanych in vitro na terapeutyczne dawki leku. Współcz Onkol 2003; 7: 260-3.

9. Bednaruk-Mtyński E, Czufryn A. Postępy w leczeniu wczesnego raka piersi - najważniejsze doniesienia z 2005 r. - sprawozdanie z konferencji. Współcz Onkol 2006; 5: 255-7.

10. Roman I. Mikromacierze DNA-perspektywy wykorzystania w badaniach skuteczności i bezpieczeństwa stosowania leków. Post Bioch 2008; 54: 107-13.

11. Bednarski D, Firestine SM. Regulation of transcription by synthetic DNA- bending agents. Chem Bio Chem 2006; 7: 1715-21.

12. Baert IL, Monté D, Musgrove EA, et al. Expression of the PEA3 group of ETS-related transcription factors in human breast-cancer cells. Int J Cancer 1997; 70: 590-7.

13. Dittmer J. Does a truncated form of the transcription factor Ets1 exist in breast cancer cells? Br J Canc 2006; 94: 176-7.

14. Park YH, Jung HH, Ahn JS, Im YH. Ets-1 upregulates HER2-induced MMP-1 expression in breast cancer cells. Bioch Bioph Res Comm 2008; 377: 389-94

15. Goueli BS, Janknecht R. Upregulation of the catalytic telomerase subunit by the transcription factor ER81 and oncogenic HER2/Neu, Ras, or Raf. Mol Cell Biol 2004; 24: 25-35.

16. Kim ES, Sohn YW, Moon A. TGF-beta-induced transcriptional activation of MMP-2 is mediated by activating transcription factor (ATF)2 in human breast epithelial cells. Cancer Lett 2007; 252: 147-56.

17. Lacroix M, Leclercq G. About GATA3, HNF3A, and XBP1, three genes co-expressed with the oestrogen receptor-alpha gene (ESR1) in breast cancer. Mol Cell Endocrinol 2004; 219: 1-7.

18. Badve S, Turbin D, Thorat MA, et al. FOXA1 expression in breast cancer-correlation with luminal subtype A and survival. Clin Cancer Res 2007; 13: 4415-21.

19. Lee MY, Joung YH, Lim EJ, et al. Phosphorylation and activation of STAT proteins by hypoxia in breast caner cells. Breast 2006; 15: 187-95.

20. Sultan AS, Xie J, LeBaron MJ, Ealley EL, Nevalainen MT, Rui H. Transcription factor Stat5 promotes homotypic adhesion and inhibits invasive characteristics of human breast cancer cell. Oncogene 2005; 24: 746-60.

21. Gooch JL, Christy B, Yee D STAT6 mediates interleukin-4 growth inhibition in human breast cancer cells. Neoplasia 2002; 4: 324-31.

22. Vandel L, Kouzarides T. Residues phosphorylated by TFIIH are required for E2F-1 degradation during S-phase. EMBO J 1999; 18: 4280-91.

23. Wang A, Schneider-Broussard R, Kumar AP, et al. Regulation of BRCA1 expression by the Rb-E2F pathway. J Biol Chem 2000; 275: 4532-6.

24. Ye C, Cai Q, Dai Q, et al. Expression patterns of the ATM gene in mammary tissues and their associations with breast cancer survival. Cancer 2007; 109: 1729-35.

25. Rapakko K, Heikkinen K, Karppinen SM, et al. Germline alterations in the 53BP1 gene in breast and ovarian cancer families. Cancer Lett 2007; 245: 337-40.

26. Prescott JD, Koto KS, Singh M, Gutierrez-Hartmann A. The ETS transcription factor ESE-1 transforms MCF-12A human mammary epithelial cells via a novel cytoplasmic mechanism. Mol Cell Biol 2004; 24: 5548-64.

27. Zahnow CA. CCAAT/enhancer binding proteins in normal mammary development and breast cancer. Breast Cancer Res 2002; 4: 113-21.

28. Ceshi C, Hina V, Bhalala HO, Dong JT. A possible tumor suppressor role of the KLF5 transcription factor in human breast cancer. Oncogene 2002; 21: 6567-72.

29. Patel NM, Nozaki S, Shortle NH, et al. Paclitaxel sensitivity of breast cancer cells with constitutively active NF-kappaB is enhanced by IkappaBalpha super-repressor and parthenolide. Oncogene 2000; 19: 4159-69.

\section{Adres do korespondencji}

\section{Marta Ziaja-Sottys}

Katedra i Zakład Biologii z Genetyką

ul. Witolda Chodźki 4 A

20-093 Lublin

tel. +48815357392

e-mail: marta.ziaja-soltys@umlub.pl 